\title{
CHANGE MANAGEMENT: CONCEPT, APPLICATION, AND ITS RELEVANCE FOR HIGHER EDUCATION MANAGEMENT
}

\author{
Iskandar \\ Universitas Kuningan, Kuningan
}

\begin{abstract}
Change is a necessity. Implementation of change management is a must for the organization, if it wants to survive and develop forward. However, in fact, not all heads of organizations are aware of and understand the importance of it. This paper explores what this concept actually is. How is the application, especially when it is associated to the contemporary demands facedby the organization.Then, how far its relevance for management at the level of praxis, especially college management. This paper has not become a comprehensive text that addresses the above theme, but rather as 'a trigger' that hopefully can stimulate serious discussions among the academic community in order to obtain a clearer, more coherent, and more complete picture.
\end{abstract}

Keywords: change management, higher education, agent of change, leadership

\section{INTRODUCTION}

"Change or die!" said C.K. Prahalad (Sudjatmiko, 2007 p 64), gave a very clear warning. The phrase was firmly reminded how important the change. Change is a necessity that must be followed if a person or an organization are going to survive.

The concept of change has been a topic of study since the days of ancient Greece. Permenides (800 BC) is a famous philosopher with his sentence: "hen panta ta" which means "change is possible". He said "things cannot change", something only "accepts the condition". In the context at that time, where people tend to be introverted and isolated, these words may be quite relevant.

But with the passage of time, the fact that appeared more contrary to the opinion of Permenides. Therefore, a philosopher named Heraclitos (530 BC) refused this view with his famous words, "panta rei" meaning "everything changes". Since then actually the seeds of philosophy of change began to be sowed. Awareness of the importance of these changes then colored the history of human thought.

There are at least 4(four) philosophy of changes that are very influential on the development of science, especially the science of management, i.e.: life cyclephilosophy, evolutionary philosophy, dialectical philosophy, and teleologicalphilosophy (Kasali, 2007, p. 246-250).

In the view of the philosophy of the life cycle, changes occur naturally as well as the life cycle: birth, grow, mature, old, dead. This view was adapted in management science manifested in the concept of "organization life cycle" and "product life cycle".

The philosophy of evolution argues that the changes occur through a sustainable cycle, namely: variation, selection, and retention. In the variation appears new forms, then there is a 
process of natural selection, there are dead and there are who/which can still survive, those who can survive then perform retention that is keeping them still exist.

Dialectical philosophy sighted bring human beings are born different. Such pluralism is in addition to encourage cooperation also potentially lead to conflict. In the process of this conflict dialectical process occurs: thesis - antithesis - synthesis. Synthesis as a "win-win" then becomes the new thesis which will encourage the emergence of a new antithesis and then gave birth to a new synthesis, and so on.

While the philosophy of teleology views that the changes are triggered by the emergence of "visionary leader". Leaders who are able to see far ahead as viewed with the aid of a telescope. Then, they formulate clear goals and objectives that the organization can move in a creative, adaptive, and interactive way toward achieving that goal. This philosophy which gave birth to the concept of "result-based management".

Today there is no word that is so magical and mysteriousexcept the word 'change'. It is even considered as something that is eternal in this world. Kasali (2006, p. xxxiii-xxxv) identified 10 (ten) characteristics of change, namely: 1) Change is mysterious, because it is not easy to be handled and controlled; 2) Change requires a "change makers" who had the extraordinary courage; 3) Not everyone can see or realize the change, only leader who has a vision of far future are able to realize it; 4) Change happens any time and encourage change with the chain; 5) There is a hard side (money, technology) and the soft side (human, organizations) of the change; 6) Change takes time, costs, and strength; 7) It takes a special effort to touch fundamental value as a source of change; 8) Change is always colored by myth; 9) Change raises expectations; and 10) Change can also cause fears and panics.

\section{Change Management: Concepts and Applications}

Sudjatmiko (2007, p. 64) defines change management as "the process of managing change from the human side." Thus, according to him, the change in terms of technology or its working processesis not included in Change Management. This is in line with the view of Kasali (2007, p.iv) who states that the Change Management "are basically not to apply the technology, methods, structures, or new managers" but "changing people's way to think and behave".

There are many versions of the Change Management disciplines. But many experts agree this science is a combination of many disciplines such as management, business, psychology, and even engineering. The disciplineof Change Management can be traced of the emergence of scientific management movement pioneered by Frederick Taylor (1911), and Edward Deming (1960) with his quality control movement, followed by Rosabeth Moss Kanter (1983) who call for the importance of continuous innovation. But among the experts, John Kotter, one who is currently regarded as the main expert in the change affairs. His book,Leading Change (1996) and The Heart of Change(1998) is regarded as a handbook on Change Management which is the most complete.

Along with the development of the discourse changes, various management experts say a few models that can assist organizations in applying change management. Prosci \& Change Management Center, for example, builds a model known by the acronym ADKAR, namely: 1) Awareness, people or members of the organization who you want to change to know and realize why changes are needed; 2) Desire, their support and participation in changes both 
come from among the leadersand members of the organization; 3) Knowledge, know how to change; 4) Ability, their ability to implement new skills and behaviors; and 5) Reinforcement, capable of sustaining the achievements of change (Pambudi, 2007, p. 60).

Various other models were developed by experts. For example,Jakarta Consulting Group (JCG), which issued "JCG Mastery of Change"; Red Pyramid developed the "Pentagon Models", while Rhenald Kasali initiated the "Re Code Your Change DNA". But whatever the model, Change Management includes three (3) important stages: planning, implementation, and management of change results.

\section{Planning Phase}

In this phase, the first step to be taken is the "sense of urgency" for all crew members of the organization. This step should be done when the organization is in good condition, because when you are in a critical condition, change will be very heavy.

The second step in this phase is to determine what you want to change, and formulate its goal. In this context, aleader must be able to build a vision and strategy, because without them, changes could occur without direction.

The third step is to build the enthusiasm of members of the organization to change. Here, the leader's ability to relate to people who are invited to change is crucial. Whatever the changes that will be built will eventually lead to "people issues" i.e.: what are the benefits of these changes for them. The enthusiasm of the employees will be awakened if they have hopes that the changes make their fate would be better.

The fourth step is to parse the competences regarding what should be fulfilled to achieve the goals of change. These strategies will bear the training needed to acquire competencies that support long-term business strategy that does not exist today. In addition to technical competency, Kasali (2007: 66) warns that more fundamental is the change of mindset. Therefore, Kasali encourage leaders pay attention OCEAN levels both for themselves and for their members. OCEAN is the acronym of: Openess to experience (open to new things); Conscientiousness (listen with heart); Extroversion (open to other people); Agreeableness (open on agreement); and Neuroticism (open to pressure).

The fifth step is to prepare the supporting infrastructures, such as: performancesystem, reward system, performance indicators, information technology, and if necessary to form a management team that is popularly called agentsof change. However, it should be realized that although there are agentsof change, leaders must keep working to involve the entire members of organization in change.

The final step in this phase is to determine the right time to initiate change. When everything was ready, the implementation phase begins. Set a target date in accordance with the needs and scale of the changes that you want to do. The target of time is important that the objectives that have been set is measurable and to get feedback to get better achivement.

\section{Planning Phase}

The implementation phase is the period of travel. In this phase, the role of the leader is determinant factor of the success of changes. In facing any situation, leaders must be able to make strategic decisions and consistently implement that decision. In managing this decision, 
communication is very important. Leaders are required to be able to communicate proactively (not reactively), the focus, and sometimes can not be delegated. It is important to maintain supports, because the change is essentially an individual trip to face uncertainty.

Employees' supports to these changes is very crucial. According to D'Aprix and Gay in Pambudi(2007, p. 62), in addressing the changes, employees are divided into 5 (five) groups, namely: a) Early adapters, are people who receive directly your change; b) Early majority, are people who recognize the need for change but not immediately accepted (hopeful); c) Undecided, are people who are waiting which way the wind is blowing (fence sitter); d) Late majority, are people who are anxious about the growing conditions, especially the impact of changes to himself; and e) Late adapters, are those who openly reject the change (resistance).

Among resistantsare believed would always be in the process of change. Leaders are required to manage this resistance wisely so that they are aware of and willing to work together to support the change. If a variety of ways (communication, education, negotiation, even manipulation) does not succeed, then the coercive action is needed (forcing to join or go).

In this second phase, besides the ability to make decisions and the ability to communicate, leaders should also create small wins. Appreciate the hard work of employees in achieving the targets of change with incentives to motivate them to work better. It is also important to make sure employees that the organization is on the right track in the process of change.

\section{End Management Phase}

If the success has not been achieved, leaders are required to correct the deficiencies and weaknesses. Meanwhile, when the success has been achieved, a leader is in the pleasant as well as harmfulsituation. The organization enters into a new comfort zone. In this context, Kotter in Pambudi (2007, p. 64) gives two formulas: a) Consolidate successes and maintain momentum; and b) Plant the existing change become a culture.

Change in an organization is starting from the leader (start at the top), but the leadership is not enough. Kasali (2007, p. 18) states that the change requires five things at once, namely: a) Vision: the vision of the future direction; b) Skills, the skills to be able to do new demands. These skills must be continually nurtured, grown and developed; c) Incentives, namely adequate incentives; d) Resources, the resources that facilitate the movement and growth; and e)Action Plan, which is integrated in the specific action plan, planned, written, and understood by all actors involved.

Figure 1: Process of Change Management

\begin{tabular}{|c|c|c|}
\hline Plannina Phase & Implementation & End \\
\hline $\begin{array}{l}\text { - Recognizing the need } \\
\text { for change } \\
\text { - What do you want to } \\
\text { change and what } \\
\text { change's goals } \\
\text { - Building enthusiasm of } \\
\text { members to change } \\
\text { - Determining the } \\
\text { needed competence } \\
\text { - Setting up supporting } \\
\text { infrastructure }\end{array}$ & $\begin{array}{l}\text { - Strategic decision } \\
\text { making } \\
\text { - } \text { Proactive } \\
\text { Communications } \\
\text { - Celebrate the } \\
\text { small victories }\end{array}$ & $\begin{array}{l}\text { - Evaluation and } \\
\text { correction } \\
\text { - Consolidate success } \\
\text { - Instill a culture } \\
\text { change }\end{array}$ \\
\hline
\end{tabular}




\section{Relevance for Higher Education Management}

In this era of globalization, the college is an organizational entity which is not only required to constantly change, but also must continue to anticipate changes. There are many challenges impacted by the globalization process that must be addressed properly by the college if it wants to continue to exist and thrive. Therefore, the application of change management in higher education is a must.

According to Atkinson (Indrajit and Djokopranoto, 2007, p. 94) the challenges facing higher education in the future requires anticipation of the managers of the college are as follows:

1) The college will change from one institution to monopolize knowledge was just so an agency of information provider. Therefore, the university will no longer monopolize the production of knowledge, but they have to compete with other information service providers.

2) The college will be changed from an institution that is limited by time and geography becomes aborderless institution. Global university will be able to teach students wherever and whenever and can take lecturers from anywhere.

3) The learning process will lead to the process of getting high-quality interaction which is based on sophisticatedinformation and communication technology.

4) The synergies and cooperation between universities internationally will become a necessity. Internationalization of the university will cover three main activities, namely: collegialactivity, collaborative activity, and entrepreneurial activity.

So, how and from where we start the change in the environment of our institutions? Gladwell in Kasali(2007, p. 173), observed that the change could come from the emergence of agentsof change who are aware of and inspired about the need for change. The influence of this agent of change will be such an epidemic of infectious disease that spreads rapidly. In the context of higher education, it would be better,the agent of change that comes from the highest leadership of the university, because of his authority, he would quickly implement the changes. However, although the agent of change does not come from the supreme leader, though the way would be more complicated and longer.

According to Gladwell (Kasali, 2007: 178) there are four rules that are very important in the process of change, namely:

1) Change begins from a few people who are able to perform the role of infection effectively.

2) Adhesive factor, that is, people who are able to convey a message so that the message of the "inherent" in the minds of many people.

3) Do not ignore the small matters, because trivial small matters can be transmitted and expandedand cannot be controlled.

4) Consider the context, that is, the most appropriate time or place to make changes.

The challenges facing higher education in the future will increasingly large and complex. Being very relevant here to hear the advice Kasali (2007: 242) that we re-encodes the DNA codes us to be more open, more responsive, and more creative. 


\section{CONCLUSION}

Change is a necessity that must be managed properly. Change always provides hope and opportunity as well as fear and anxiety. Managing them needs the right strategy and a clear program, and more importantly, it needs courage. Here the leadership factor plays an important role but is not everything. The most determinant factor is the mental attitude to want to change, leaving the comfort zone that had been attached into our habits change moving towards the "Uncharted territory", an area that has not been mapped yet challenging to do.

\section{REFERENCES}

Indrajit, R. Eko dan Djokopranoto, R; (2006); Manajemen Perguruan Tinggi Modern; Andi; Yogyakarta.

Kasali, Rhenald (2006); Change !; PT Gramedia Pustaka Utama; Jakarta.

(2007); Re-Code Your Change DNA, Membebaskan Belenggu-belenggu untuk Meraih Keberanian dan Keberhasilan dalam Pembaharuan; PT Gramedia Pustaka Utama; Jakarta.

Pambudi, Teguh S; (2007); Mengayuh Sepeda Meniti Uncharted Territory; Majalah SWA Sembada Nomor 03/XXVIII/1 - 4 Februari, Hal 60-65.

Sudjatmiko, Steve; (2007); Change Management: Sejarah dan Masa Depannya; Majalah SWA Sembada Nomor 03/XXVIII/1 - 4 Februari, Hal 64-65. 